\title{
STREET LAW AND ITS ROLE IN ENSURING ACCESS TO JUSTICE AND FURTHERING OF THE SOUTH AFRICAN DEMOCRACY
}

By Mlungisi Mahlangu*

\section{Introduction}

'When two bull elephants fight, it is the grass that suffers'

- Jomo Kenyatta

It has always been with a bit of introspection and guilt that I have considered this statement by the great statesman. However to what extent is this statement still relevant, given the backdrop against which Kenyatta made these infamous words?

Surely, Kenyatta spoke of some sort of intense political battle, waging between coloniser and the rebellious or guerilla political movements of the colonised. Surely this analogy that Kenyatta spoke of decades ago ceases to exist in modern times, as the concretisation of rights has occurred, and no such battle can even exist in modern society.

The above conceptions, although ideologically ideal are practically flawed. A new form of battle is waging war. A new form of battle is waging war. As a consequence of the worldwide acceptance of the political philosophies of democracy and democratic governance, ancillary philosophies like the economic philosophy of capitalism have become intrinsic in society. What we have experienced is rather a shift from this fight for democracy between the colonisers and indigenous African people, to a fight for supremacy between those who advocate individual and those who articulate communal interests.

\section{Street law}

'Street law tells people about laws that affect them in their everyday life on the street.' This definition, as simplistic as it may seem,

Third year LLB student (University of Pretoria).

1 D McQuoid-Mason (ed) Street law: Practical law for South Africans (2nd edition) (2004) 1. 
proposes that law should be engaged in a way which would constitute a radical departure from what has been the norm. Street law operates in such a way as to challenge law as a tool for the observing the status quo or as an account of the 'popes, kings and queens'. 2 'Street law is meant to offer practical advice which should permeate deeply into society by removing the perception of the law as a means by which the rich exploit the poor, and rather showing it as a means to address specific problems within an individual's life by offering relevant remedies and advice.

In my opinion, however, street law does more than just report on the law or the present legal position. By creating opportunities for communities or groups to be addressed on the law the law is taken to the communities, not with the goal that they will absorb it like a sponge, but rather with the hope that a sector of society that has not yet been indoctrinated in 'legal logic' may critically engage in the law. This transparency will allow those deficiencies which are nontechnical and can hence be seen more clearly by those outside the profession, to be exposed, hence creating an opportunity for the legitimacy of our laws to be gauged.

\section{Hierarchy}

The idea of hierarchy has been closely linked to the contention that legal education does not allow students and subsequent legal practitioners to break free from narrowly defined boundaries, which seek only to serve the status quo. ${ }^{3}$

The main proponent of this theory is Duncan Kennedy. ${ }^{4}$ Kennedy's main contention is that law schools only prepare students for hierarchy, hence rendering them unable to change the status quo which is represented by such hierarchy. ${ }^{5}$ He contends that the mechanical analytical manner in which students are taught further derogates from this ability to challenge the law.

Hierarchy creates a status quo which is comfortable, with endless promises like 'if you sell your soul to this cause, all your needs will be taken care of'. Most students strive to be offered employment by the top five law firms in the country. These firms are given optimal

2 DP Visser 'The legal historian as subversive or killing the Capitoline geese' in DP Visser (ed) Essays on the history of law (1989) 1-31.

3 D Kennedy 'Legal education as training for hierarchy' in D Kaireys The politics of law (1998) 54-75.

4 As above.

$5 \quad$ Kennedy (n 3 above) 55. 
marketing space on campus; ${ }^{6}$ internship programmes are organised with them and are purported as being the epitome of opulence and wealth. The idea that only working for a corporate law firm can assist someone to climb the social ladder is confirmed by the lack of interest in NGO's and rights organisations as viable potential places for one to go post-LLB.

Apart from law schools focusing on the skills and knowledge which would be useful in practice, the Attorneys Act 53 of 1979 recognises that the only way that one can get admitted as an attorney of the Supreme Court is by serving a period of articles of at least one year under a principal who is in practice. The most obvious outcome of this is that even after tertiary education, students who wish to break free from the hierarchical mould are unable to become practising attorneys without succumbing to that self-same ideological system which they are to depart from.

Although the Attorneys Act does not require that the period of articles are served in private practice, students are rarely ever told of the options available to them outside of private practice, almost as if their options are limited to choosing from within firms in private practice. Many universities also have a compulsory subject dedicated to training students for practice.

From the get go, students are told of what it will take to be an advocate or an attorney, and students are introduced to this thought that they are not lay people and that law is best left to those who understand it best. This is illustrated by the limitations to right of appearance in even the Magistrates Courts, the emphasis on stare decisis and even the use of terms like legal logic and lay person.

Everyone has the right, and should be encouraged, to participate actively in the law and law-making process. ${ }^{7}$ This need to leave law to those who best understand it somewhat usurps the right of everyone to participate in the law and creates a barrier, sustained by legalese and Latin, for lay people who want to engage in the law. Numerous theories exist to explain why legal education has not progressed to 'lay the foundations for a democratic and open society in which government is based on the will of the people and every citizen is equally protected by the law', as is required by our Constitution. One of the most convincing is that legal practice has not progressed in its thinking and methodology, and hence continues to

6 Good examples of how this happens includes the career days which are organised primarily for the law firms to market themselves; and the procurement by the Law House Committee for Law Students of the services of a former student who has gone into practice to motivate first year students during orientation week, and subsequently tell them about what it takes to be hired by one of the top law firms in the country.

7 H Botha 'Civic republicanism and legal education' (1999) Codicillus 23. 
influence education which essentially aims to create good students for practice and hence aligns itself to cater for the needs of practice.

Although this may seem like a gross limitation to the role of legal education, I am reminded of the re-igniting of the debate on the adequacy of methods of evaluation within Law Faculty of the University of Pretoria after an article was published in 2006 stating that law schools are not adequately equipping students for practice that being practice at possible on of the big five law firms. The lack of numeracy and literacy skills among LLB graduates, of which practice complained was a problem which had existed for a long time, but was, in my opinion, only really engaged after this complaint from practice. It seems almost that legal education does not owe a duty to the student to equip them for life, but rather a duty to practice to keep producing good future candidate attorneys.

An interesting commentary as to the inability of lawyers to challenge the status quo comes from John Dugard, ${ }^{8}$ read in conjunction with the academic challenge posed by Karl Klare. ${ }^{9}$ The writings of these two academics, although separated by decades, contains very salient features which interrelate and somewhat explain ${ }^{10}$ and then reflect on ${ }^{11}$ the reason why legal education has not progressed to embrace our new constitutional dispensation. As stated by Dugard:

South African judges are all drawn from one small section of the population - the white group. Whether they support the government or not, most have one basic premiss (sic) in common - loyalty to the status quo. This premiss (sic), which seldom surfaces in judicial decisions, may manifest itself in a variety of ways, depending upon the background and outlook of each judge. For instance, it may take the form of opposition to social intercourse between races, of antagonism to radical political change; of sensitivity to foreign criticism of the Republic ... the South African Judiciary has become 'establishment minded'. ${ }^{12}$

Dugard then follows this up by stating that judges hide behind the veil of precedent and that upon deciding a case they have already made their mind up, they only wish to justify their decision by means of the law. ${ }^{13}$

Klare, decades later, somewhat confirms the views of Dugard, but adds a new dimension to this. Klare states that the reason why there

J Dugard 'The judicial process, positivism and civil liberty' (1971) South African Law Journal 181. The basis of this article was initially an inaugural lecture by Dugard who, at the time, was inducted into being a professor at the somewhat liberal University of the Witwatersrand.

9 KE Klare 'Legal culture and transformative constitutionalism' (1988) South African Journal on Human Rights 146.

10 Dugard ( 8 above) 181.

11 Klare (n 9 above) 146.

12 Dugard ( 8 above) 190

13 Klare (n 9 above) 10. 
may be very little change in the nature of our legal profession is because there has been very little change in the mindset of the judiciary:

The Constitution invites a new imagination and self-reflection about legal method, analysis and reasoning consistent with its transformative goals. By implication, new conceptions of judicial role and responsibility are contemplated. Judicial mindset and methodology are part of the law, and therefore they must be examined and revised so as to promote equality, a culture of democracy and transparent governance. Accordingly, the drafters cannot have intended dramatically to alter substantive constitutional foundations and assumptions, yet to have left these rights and duties to be interpreted through classical legalist methods ... the Constitution suggests not only the desirability, but the legal necessity, of a transformative conception of adjudicative process and method. ${ }^{14}$

At the end of the day, judges make the final decision and advocates will only argue based on what will help win the case. As a consequence, attorneys only brief the advocates on the basis or starting point of established law, the so-called Roman-Dutch legal tradition, as this is what appeals mostly to judges. Hence law schools only train their students on the basis of that which will enable them to survive in practice - thereby re-entrenching the status quo ante.

\section{$4 \quad$ A new order?}

This radical new order spoken of, in which the idea of protecting individual rights should become integrated with the idea of litigating to advance a clients pecuniary interest' seems at first guise to be a very noble means of protecting those who cannot protect themselves. It seems to be in the same vein as the transformative constitutionalism of which Klare speaks so highly. However, upon closer inspection, it exhibits the same flaws as early human rights discourse and ultimately renders this whole new order superfluous.

This proposed new order lays strong emphasis on the recognition of individual rights. The recognition of individual rights, although an important exercise is however tainted by capitalism and selfishness and hence cannot, in many instances, be reconciled to the goals of rectifying the inequalities and injustices facing South African society.

This is by no means a proposal for us to return to the Hobbesian conception of a social contract, but rather an indication that there are challenges that are faced in society, linked to or correlating with capitalism and individualism. I will not, however, lobby the ideas of Nozick whilst relegating those of Rawls to a purist departure from the spirit of moral logic. That is a task of another day. 
A strong emphasis on individual rights entrenches capitalism and some of the malpractices associated with it, as it allows room for justification of certain capitalist exploitative practices by allowing those who perpetrate them to call on certain constitutionally entrenched rights and values like individual autonomy, limited interference by the state in the affairs of the individual, freedom to contract and the right to follow ones trade of choice. ${ }^{15}$

A strong emphasis on individual rights would favour those with the resources to enable them to be able to protect those rights fully. What needs to occur is a shift from the current misnomer that individual rights are sufficient in bringing about wide ranging social change. Individual rights, especially socio-economic rights, are relative and programmatic - being heavily dependent on the state capacity to provide for them. ${ }^{16}$ What is needed in the (South) African interest is a stronger emphasis on communal and group interests, than those conflicting interests of individuals. Hansungule ${ }^{17}$ correctly points out that the recognition of third generation rights is a key move from the recognition of the individual and his rights to those of the group as a whole. This will be further strengthened by Ubuntu, which will ensure that there is communal integration and co-operation which is necessary to ensure the redress of past ills and inequalities. It is very difficult and somewhat unwise to attempt to address on the individual level, problems which have persisted and been perpetuated on a communal level.

\section{$5 \quad$ Street law and the new order}

Street law, as a social movement, aims to inform people of their rights. This is important in terms of the contribution that it can make to the new order, as with its strong emphasis on individual rights requires some form of mechanism for distributing its message of individual rights. To put this differently, it will be very difficult to imagine a protection, under the new order, of rights of which no one has any knowledge. Street law can be the vehicle through which the message on rights can be delivered in order to create an awareness and understanding of rights.

I propose street law as a social movement, rather than just an academic exercise, due to the importance that rights dialogue and

15 Although these all seem like strong private law conceptions which, theoretically, should be subject to Constitutional scrutiny, the private law has remained firmly in the grip of Roman-Dutch law and its principles. In some instances, as Botha has stated, it is a common mistake by students to interpret the Constitution in light of Roman-Dutch principles, as opposed to the other way around. Botha ( $\mathrm{n} 7$ above).

16 Unpublished: $M$ Hansungule 'Human rights conception from the standpoint of African perspective' unpublished article, University of Pretoria, 2004.

17 As above. 
awareness plays. It has been said that poverty is the absence of all rights. Although this may seem a bit radical, this notion is highly correct. Poverty reduces and diminishes ones enjoyment of life and is normally coupled with a gross absence of other fundamental rights. Should things be viewed from this level, awareness of rights, of which street law can be a strong proponent, is the first step to securing critical rights for those who right seemed ancillary to the aims of society.

Street law will also give this abstract notion of the law a face, in the sense that it is individuals who engage with other individuals on a personal level, as opposed to the norm of litigation being the point of convergence for individuals in their direct engagement with the law. The law, which for many years represented a coercive means to control the lives of people, ${ }^{18}$ can now be introduced as a vehicle through which people can claim and obtain an improvement of their personal position. ${ }^{19}$ This self-same legislation creates positive obligations on the state to be transparent, fair in decision making, and to eliminate obstacles to equality.

The importance of street law operates on many distinct and differing levels, one of which was poignantly summarised by Terri Sussel: 20

For most legal scholars, the operation and viability of legal systems is closely related to citizens' views about law, justice, and the legal authorities - views which have been described as constituting legal culture.

Currently, and due to our history, the citizen's view on the law is not one of a social instrument aimed at protecting the most vulnerable, but rather as a means by which ones freedoms are limited and curtailed. It is important for street law to show that law is merely a means of social regulation and not restriction, aimed at ensuring maximum benefit possible for each member of society.

Legislation such as the Immorality Act 5 of 1927, Black Administration Act 38 of 1927, Group Areas Act 41 of 1950 and so on are examples of legislation which was aimed to control and regulate even the most personal aspects of individuals and their lives. This legislation has now been repealed.

Our new dispensation has attempted to do this by introducing, inter alia, the Promotion of Access to Information Act 2 of 2000 and the Promotion of Administrative Justice Act 3 of 2000, and the Promotion of Equality and Prevention of Unfair Discrimination Act 4 of 2000. Through this legislation the government has re-enforced its commitment to advancing communal interests and creating burdens and obligation upon itself, as opposed to sustaining burdens on the population, as the now repealed legislation cited in footnote 20 did.

20 TA Sussel Canada's legal revolution: Public education, the Charter, and human rights (1995). Although Terri Sussel is a Canadian scholar and her book is based on the Canadian system, the South African Bill of Rights is based on its Canadian counterpart. This hence provides invaluable insight into the types of problems that the Canadians may have or have had during their post-Constitutional teething phase and hence provide us with insight into how best we can manage similar or analogous problems. 
Street law can be used as a model of learning and teaching to shape the legal and social culture by ensuring that it remains relevant to the target group. By creating dialogue to people who would be affected and interested in a particular aspect of the law, a level of legitimacy is extended to the law. Also, new ideas are imparted and canvassed with people, hence moving away from the conception of the law as an instrument of popes, kings and queens. This accessibility of the law will add to its transparency and open the doors for a truly 'open and democratic society founded on human dignity, equality and freedom'21 and hence 'heal the divisions of the past and establish a society based on democratic values, social justice and fundamental human rights'.

Essentially, street law encompasses a deep and critical understanding of the law, which encourages people to leave their 'airconditioned offices in their ivory towers'. ${ }^{22}$ The law is what happens in the street, not in textbooks. Street law should seek to influence and encourage other legal academics to shift the emphasis and presentation of their modules from those that promote pecuniary interest through the over-reliance on the status quo. With the shift to democracy, legal education should have got on the wagon, and followed suit in transforming its emphasis to one which recognises that the so-called value system or grundnorm of our society has changed.

The starting point for legal education, as envisaged by street law, should not be what the current position legal position is, or what our far-removed uncles, Voet, Van Der Keesel or Grotious had to say about the matter. It should rather be what would best address the societal needs of the time. In order for our law to be effective it must be relevant and sensitive to the needs of the time and the people.

Street Law achieves this by continually engaging with people, thereby being in a position to hear of their needs, concerns and fears.

The emphasis of street law should be providing legal advice to indigent people at a pre-legal clinic level, thereby opening up the doors for the law to be equally enjoyed by all. The best means of achieving this objective is by either establishing a society of law students, committed to teaching others about legal topics which affect them in their daily lives; or alternatively requiring all academic staff in the law faculty, including tutors and academic assistants, to, in addition to any research or other requirement of their employment, have to meet a certain benchmark in 'street law hours' during each academic year. This benchmark would be reached by either offering a free advisory service in a particular geographical area or industry, 
which aims to inform those in that area of the law. Such advisory service would have to be well-marketed. An alternative to the former approach would be to require such staff to give a certain number of workshops or other information sessions to a targeted audience outside of the university and its academic circles.

Although the above would be a requirement for all academic staff, it should be left open as an avenue for any law student or legally inclined person to pursue. However, due to the danger of letting people loose on the community without being adequately informed, a street law co-ordinator should be appointed to manage and coordinate all the street law activities of a faculty. Allowing all students to engage freely with the law and the community it affects will not only allow them to add value to their degrees but will serve as a further deepening of the aims of street law itself.

Street law aims to reconcile the interests and ambitions of the wealthy, with the needs and struggles of the very desolate, thereby creating some form of just legal order as was envisaged by former President Nelson R Mandela, on a plaque which symbolically features prominently in the lobby of the Constitutional Court, which reads ' $\mathrm{A}$ ] society is not judged by how it treats its most affluent citizens, but rather by how it looks after the most vulnerable and poor inhabitants'. 